\begin{tabular}{|l|l|l||}
\hline \multicolumn{2}{|c|}{ PublisherInfo } \\
\hline \hline PublisherName & $:$ & BioMed Central \\
\hline \hline PublisherLocation & $:$ & London \\
\hline \hline PublisherImprintName & $:$ & BioMed Central \\
\hline \hline
\end{tabular}

\title{
Damage in worms
}

\begin{tabular}{|l|l|l||}
\hline \multicolumn{2}{|c|}{ ArticleInfo } \\
\hline \hline ArticleID & $:$ & 4370 \\
\hline \hline ArticleDOI & $:$ & $10.1186 /$ gb-spotlight-20020107-01 \\
\hline \hline ArticleCitationID & $:$ & spotlight-20020107-01 \\
\hline \hline ArticleSequenceNumber & $:$ & 36 \\
\hline \hline ArticleCategory & $:$ & Research news \\
\hline ArticleFirstPage & $:$ & 1 \\
\hline \hline ArticleLastPage & $:$ & 2 \\
\hline \hline & $:$ & RegistrationDate : 2002-01-07 \\
ArticleHistory & $:$ & OnlineDate \\
\hline \hline ArticleCopyright & $:$ & BioMed Central Ltd2002-01-07 \\
\hline \hline ArticleGrants & $:$ & \\
\hline \hline ArticleContext & $:$ & 130593311 \\
\hline \hline
\end{tabular}




\section{Jonathan B Weitzman}

Email: jonathanweitzman@hotmail.com

The DNA damage response (DDR) is essential for normal cell function and for tumour suppression. In the January 4 Science, Simon Boulton and researchers at the Dana-Farber Cancer Institute, Boston, report a strategy to identify novel DDR genes (Science 2002, 295:127-131). They combined functional genomics approaches, namely protein-protein interaction mapping and high-throughput phenotype analysis, to investigate DDR in Caenorhabditis elegans. They chose 75 worm genes representing orthologs of proteins involved in nucleotide-excision repair (NER), mismatch repair (MS), base-excision repair (BER) or non-homologous end joining (NHEJ), and tested them in the yeast two-hybrid proteinprotein interaction assay. They confirmed interactions observed in other species and found new interacting partners. Proteome-wide interaction screening identified a large number of 'interologs', enabling Boulton et al. to construct a DDR protein-interaction map. They validated candidate genes using the 'RNAi by feeding' method, and looked for DDR phenotypes following irradiation. This combined approach led them to identify 12 DDR orthologs in worms and 11 novel DDR-related genes. The authors propose that similar strategies, integrating high-throughput protein interaction screens and RNAi phenotype analysis, could generate genomic maps for DDR and other biological processes in mammalian cells.

\section{References}

1. The DNA damage response: putting checkpoints in perspective.

2. Science, [http://www.sciencemag.org]

3. Dana-Farber Cancer Institute, [http://www.dfci.harvard.edu]

4. A biological atlas of functional maps.

5. Potent and specific genetic interference by double-stranded RNA in Caenorhabditis elegans. 